\title{
Archiwa słowackie w oczach archiwistów spiskich - historia i dzień dzisiejszy
}

Terytorium dzisiejszej Słowacji od średniowiecza aż po rok 1918 znajdowało się w granicach Królestwa Węgier (monarchii austro-węgierskiej), jako integralna część tego państwa, nieposiadająca żadnej autonomii. Po upadku monarchii austro-węgierskiej powstała Czechosłowacja, która - z przerwą w czasie II wojny światowej - przetrwała do 1993 r., kiedy Słowacja stała się odrębnym, niepodległym państwem. Mówiąc zatem o archiwach słowackich, należy mieć na uwadze, że do $1918 \mathrm{r}$. de facto i de iure były to archiwa węgierskie, działające na terytorium dzisiejszej Słowacji. Również w czasie istnienia Czechosłowacji, pomimo pewnej niezależności władz archiwów słowackich, centrum decyzyjne znajdowało się w Pradze. Samodzielna archiwistyka słowacka - jeśli można użyć takiego sformułowania - ma w związku z tym dosyć krótką historię, co oczywiście nie oznacza, że nie wyrosła ona na działaniach poprzedników.

Pomimo prawie dwudziestopięcioletniego sąsiedztwa Polski ze Słowacją jako suwerennym państwem, ciągle aktualne są słowa Wojciecha Stępnia, który w $2009 \mathrm{r}$. napisał, że polska literatura dotycząca archiwów słowackich nie jest zbyt obszerna ${ }^{1}$. Paradoksalnie, gdyż nasi historycy obficie korzystają z archiwaliów przechowywanych na Słowacji. Wyrazem tego są m.in. edycje źródłowe przygotowane przez S. Srokę czy publikacje np. R. Grzesika, J. Kurtyki, T. M. Trajdosa ${ }^{3}$ oraz skromne przyczynki piszącego te słowa ${ }^{4}$. Środowisko małopolskich badaczy włącza się

\footnotetext{
${ }^{1}$ W. Stępień, Archiwa Państwowe na Stowacji: organizacja, działalność, zasoby, „Teki Archiwalne" T. 10, 2009, s. 47.

${ }^{2}$ Dokumenty polskie z archiwów dawnego Królestwa Węgier. T. 1-5, Kraków 1998-2012.

${ }^{3}$ Patrz literatura w: Historia Scepusii. Vol. 1, vad. red. M. Homza, S. A. Sroka, Bratislava 2010; Vol. 2, vad. red. M. Homza, S. A. Sroka, Bratislava 2016.

${ }^{4}$ R. Jop, Dokument Bolesława Wstydliwego dla Podolinca $z 1244$ r. Próba nowej interpretacji, „Spiš. Vlastivedný zborník” T. 6, 2012, s. 60-81; tenże, W sprawie metod badania granic
} 
ponadto w istotne przedsięwzięcia wydawnicze dotyczące Spiszu, jak Terra Scepusiensis. Stav bádania o dejinách Spiša ${ }^{5}$ i Historia Scepusii ${ }^{6}$. Kraina ta, jako pograniczna, obecnie położona na terytorium Polski i Słowacji i przedzielona na szczęście dość efemeryczną granicą, jest także przedmiotem zainteresowania działającego w Krakowie Towarzystwa Słowaków w Polsce. Jego współpraca z kolegami z południa zaowocowała w 2015 r. wydaniem dziewiętnastowiecznej wizytacji dekanatu dunajeckiego, obejmującego także obecne ziemie polskie ${ }^{7}$. O tym, jak wiele jeszcze interesujących źródeł kryją słowackie archiwa w sprawie polskiej obecności na Spiszu, świadczy wydana w 2015 r. Kniha testamentov meštanov mesta Stará Lubovňa $1660-1747^{8}$.

Niniejszy artykuł powstał w oparciu o publikacje wydane w 2016 r. w roczniku „Z minulosti Spiša”, prezentujące dzieje archiwów słowackich oraz bieżącą działalność archiwów spiskich w Lewoczy, Spiskiej Nowej Wsi, Popradzie i Starej Lubowli ${ }^{9}$.

Struktura władzy i administracji w średniowiecznym Królestwie Węgierskim nie odbiegała od reszty Europy łacińskiej, opierała się na istnieniu władzy świeckiej i kościelnej i takich samych podziałach administracyjnych, które niejednokrotnie się przenikały. Nie może więc dziwić, że te dwa średniowieczne czynniki sprawcze wytwarzały w warunkach węgierskich przeważającą część produkcji aktowej, przede wszystkim w postaci dokumentów. Najwięcej średniowiecznych dokumentów dotyczących ziem słowackich zachowało się w archiwach kościelnych. Po pierwsze, wynikało to z faktu, że Kościół jako instytucja był odbiorcą przywilejów i nadań monarszych oraz beneficjentem osób prywatnych. Po drugie,

średniowiecznych, [w:] Nauki pomocnicze historii. Teoria, metody badań, dydaktyka, red. A. Jaworska, R. Jop, Warszawa 2013, s. 239-252; tenże, Delimitacje Podolinca z Toporcem w XIII-XVIII w. Z dziejów kształtowania się granicy linearnej na Spiszu, „Res Historica” Nr 35, 2013, s. 31-47.

${ }^{5}$ Terra Scepusiensis. Stav bádania o dejinách Spiša, vad. red. R. Gładkiewicz, M. Homza, Levoča 2003.

${ }^{6}$ Historia Scepusii. Vol. 1, vad. red. M. Homza, S. A. Sroka, Bratislava 2010; Vol. 2, vad. red. M. Homza, S. A. Sroka, Bratislava 2016.

${ }^{7}$ J. Šimončič, K. Karabová, Kanonické vizitácie Dunajeckého dekanátu v Spišskom biskupstve z roku 1832, Krakov 2015.

${ }^{8}$ Kniha testamentov meštanov mesta Stará Lubovňa 1660-1747, ed. F. Marcinová, P. Žarnovský, Stará L'ubovňa 2015.

${ }^{9}$ H. Bilská, Z dejín Štátneho archívu v Starej Lubovni, „Z minulosti Spiša” T. 24, 2016, s. 237245; I. Chalupecký, K problematike štátnych a cirkevných archívov na Slovensku, tamże, s. 185-199; E. Dzurillová, Anabáza Okresného archívu v Levoči, tamże, s. 209-221; B. Malovcová, Popradský archív v prúde času, tamże, s. 227-237; N. Palková, Pohlad do 6o-ročnej činnosti štáneho archívu $v$ Spišskej Novej Vsi, tamże, s. 221-227; F. Žif̌cak, Štátny archív v Levoči a ochrana archívneho dedičstva, tamże, s. 199-209. 
kapituły i klasztory były swego rodzaju gwarantem poczynań administracyjnych i prawnych władców. Wyrażało się to w funkcjonowaniu w Królestwie Węgierskim do XVIII w. tzw. „vierohodných miest” (loca credibilia) - w dosłownym tłumaczeniu „wiarygodnych miejsc” - przypominających instytucję notariatu publicznego w średniowiecznej Polsce. Loca credibilia działały poprzez osobę notariusza przy niektórych kapitułach (np. Nitra, Bratysława, Spiska Kapituła) i niektórych klasztorach (np. św. Benedykt nad Hronem, Jasów, Lelesz). Posiadały pieczęć autentyczną, wydawały własne dokumenty, wystawiały dokumenty w imieniu osób trzecich, potwierdzały dokumenty innych wystawców i z rozkazu panującego wraz z jego przedstawicielami uczestniczyły $\mathrm{w}$ różnych prawnych czynnościach związanych z nadaniami oraz z obrotem ziemią. W związku z takim zakresem działalności prowadzone były protokoły czynności oraz tworzono kopie wystawianych dokumentów, które przechowywano we własnym archiwum. Loca credibilia wytworzyły większość zachowanych do dzisiaj dokumentów dotyczących ziem słowackich.

Od XIII w. administracja publiczna i sądownictwo znalazły się w rękach komitatów, czyli władz prowincjonalnych, zwanych też stolicami lub żupami, oraz władz wolnych miast królewskich. Instytucje te, posiadając własne archiwa, przekazywały każdorazowo ich zasób nowo obranym urzędnikom, co często wiązało się ze zmianą miejsca przechowywania dokumentów i ksiąg. Narażało to akta na niebezpieczeństwo zniszczenia. Sytuacja archiwów komitatów oraz miast polepszyła się wraz z powstaniem domów żupnych i ratuszów, jako siedzib lokalnych władz. Oczywiście budowle te były narażone na pożary, co spowodowało, że zachowane księgi komitatów pochodzą dopiero z XVI w. Akta miejskie sięgają XIV-XV w. (Bratysława, Bardejów, Preszów, Koszyce, Nitra). Dla współczesnych miast słowackich jest to materiał cenny źródłowo i historycznie. Warto dodać, że średniowieczne księgi władz Wiednia zachowały się w nielicznych egzemplarzach, a sąsiednia Bratysława ma ich kilkadziesiąt $\mathrm{z}$ samego XIV w.

Archiwa tworzyły także najznaczniejsze rody szlacheckie posiadające majątki na terenach dzisiejszej Słowacji. Przechowywano w nich to wszystko, co dotyczyło praw majątkowych oraz przywilejów otrzymywanych od władców węgierskich.

W średniowieczu i we wczesnym okresie nowożytnym największą troskę o archiwa wykazywały klasztory oraz loca credibilia, co wynikało z ich pozycji i pełnionych funkcji, chociaż w obydwu przypadkach nie udało się uniknąć strat. Na szeroką skalę arcybiskupstwa, biskupstwa i żupy świadomie zainteresowały się własnymi archiwaliami w XVIII w. Zaczęły wtedy powstawać pierwsze spisy i inwentarze, rozpoczęło się ewidencjonowanie zasobu. Żupy w XVIII w. zatrudniały archiwistów, którzy zajmowali się archiwami władz komitatu i podległych 
instytucji. Proces ten nasilił się w połowie XIX w. wraz z rozwojem biurokracji i zalewem powstającej dokumentacji aktowej, którą trzeba było segregować, klasyfikować i w części brakować. Ważną rolę dla rozwoju archiwów na ziemiach Słowacji miało powstanie w Budapeszcie w 1874 r. Węgierskiego Archiwum Państwowego, którego zasób stał się stopniowo przedmiotem zainteresowania historyków.

Przed 1918 r. o własne archiwa dbały tylko te miasta, które dysponowały przygotowanymi do pracy ludźmi lub były w stanie ich zatrudnić. Przede wszystkim były to: Koszyce, Bratysława, Bardejów, Preszów, Spiska Nowa Wieś, Lewocza, Trenczyn oraz Bańska Bystrzyca. Archiwa tych miast porządkowali albo miejscowi archiwiści, jak np. w Lewoczy profesor tamtejszego gimnazjum Koloman Demkó, albo zawodowi historycy, jak Béla Iványi, który skatalogował dokumenty miasta Bardejowa.

Archiwa szlacheckie zaczęto porządkować w przypadku najznaczniejszych rodów w XVIII w. (rodziny Esterházych, Andrássych, Csákych, Erdődych). W XIX w. powstawały inwentarze i skorowidze do przechowywanych archiwaliów. Dla ocalenia archiwów wielu rodzin istotne znaczenie miało to, że ich przedstawiciele $\mathrm{z}$ własnej inicjatywy deponowali swoje akta rodowe najpierw w Węgierskim Muzeum Narodowym, a następnie w Węgierskim Archiwum Narodowym.

W 1918 r., po rozpadzie monarchii austro-węgierskiej i powstaniu Republiki Czechosłowackiej, ogromna część inteligencji węgierskiej opuściła terytorium Słowacji i osiedliła się na Węgrzech. Wśród tej grupy było wielu archiwistów. W 1919 r. powstał Państwowy Inspektorat Archiwów i Bibliotek w Bratysławie, który miał roztoczyć opiekę nad istniejącymi archiwami, ale ze względu na to, że zatrudniał tylko jednego inspektora, działalność tej instytucji nie odpowiadała potrzebom chwili. W 1922 r. zlikwidowano żupy, a ich archiwa poddano pod nadzór władz powiatowych (okresný úrad), które nie poświęcały im stosownej uwagi. W $1928 \mathrm{r}$. po reformie administracyjnej powstał w Bratysławie Urząd Krajowy (Krajinský úrad), podległy Ministerstwu Spraw Wewnętrznych (dalej MSW), który sprawował pieczę nad urzędami powiatowymi w słowackiej części kraju. Zorganizowano przy nim Archiwum Krajowe, które miało wykwalifikowanych archiwistów, a ich zadaniem było objęcie nadzorem miejscowych archiwów. Misję tę przerwała II wojna światowa, dlatego wiele archiwaliów pozostało w złym stanie i bez opieki.

Zmiany w sieci archiwów na Słowacji oraz nowy sposób podejścia do archiwistyki nastąpiły po zakończeniu II wojny światowej. Po przejściu frontu ucierpiały szczególnie archiwa będące w posiadaniu właścicieli ziemskich, najczęściej znajdujące się w dworach. Archiwa te oraz prywatne biblioteki były rozgrabiane i niszczone. W 1950 r. władze komunistyczne zlikwidowały w Czechosłowacji wszystkie 
męskie klasztory. Ich archiwa i książnice albo uległy zniszczeniu, albo poszły w rozproszenie, część trafiła np. do biblioteki reaktywowanej przed wojną Macierzy Słowackiej, instytucji kultury pielęgnującej wartości narodowe. W związku z konfiskatą majątków ziemiaństwa i reformą rolną w 1947 r. przy czechosłowackim Ministerstwie Rolnictwa i Reformy Rolnej powstało Archiwum Ministerstwa Rolnictwa. Jego celem było przejęcie na własność archiwów skonfiskowanej własności ziemskiej i przedsiębiorstw leśnych, zanim nie zostały doszczętnie zniszczone. Archiwum to miało na Słowacji 6 oddziałów. Pracowali w nich młodzi archiwiści, którzy chodzili po pałacach i dworach, wynajdowali archiwalia, gromadzili je $\mathrm{w}$ archiwach i ewidencjonowali, dzięki czemu wiele $\mathrm{z}$ nich ocalało.

W związku z nacjonalizacją górnictwa i hutnictwa w 1950 r. powstało w Bańskiej Szczawnicy Centralne Archiwum Górnictwa, gdzie zgromadzono z całego kraju materiały archiwalne pozostałe po działalności kopalni i hut. Dawne Archiwum Krajowe w Bratysławie zostało przekształcone w 1945 r. w Archiwum Ministerstwa Spraw Wewnętrznych, a w 1952 r. w Słowackie Archiwum Centralne. Jego celem było zgromadzenie i opracowanie akt organów centralnych i sądów słowackich.

Dawne archiwa żup w 1945 r. dostały się pod nadzór władz krajów, co w znacznym stopniu przyczyniło się do ich zniszczenia z powodu braku zainteresowania i złych warunków przechowywania.

Dla rozwoju archiwów i archiwistyki słowackiej po II wojnie światowej wielkie znaczenie miało powstanie Katedry Archiwistyki i Nauk Pomocniczych Historii na Wydziale Filozoficznym Uniwersytetu Komeńskiego w Bratysławie. Od 1950 r. zaczęła ona kształcić archiwistów, kładąc nacisk na znajomość nauk pomocniczych historii, łaciny, języka niemieckiego i węgierskiego, z racji specyfiki materiałów archiwalnych znajdujących się w słowackich archiwach.

Archiwa słowackie jeszcze w okresie międzywojennym podlegały MSW. Pierwszym krokiem do zorganizowania jednolitej sieci archiwów w Czechosłowacji było utworzenie w 1953 r. w Pradze Departamentu Archiwistyki przy MSW, jako naczelnego organu administracyjnego. Zaraz potem powstał w Bratysławie podległy Pradze departament ds. archiwów na Słowacji, posiadający znaczną samodzielność. Warto dodać, że w początkowym okresie istnienia tej instytucji zatrudnione były w niej 4 osoby: delegowany z MSW milicjant, który pomimo tego, że sprawował „opiekę" nad pozostałymi pracownikami, to ze względu na swoje zainteresowania i zapał do pracy w archiwum stwarzał im warunki do pracy archiwalnej i badań naukowych. Pozostałymi pracownikami departamentu byli dwaj profesorowie filologii klasycznej, którzy nie znaleźli pracy w szkołach, ponieważ zlikwidowano w nich lektorat $\mathrm{z}$ łaciny, oraz jeden archiwista $\mathrm{z}$ wykształcenia. 
Początki zorganizowanej archiwistyki w Czechosłowacji zaczynają się w 1954 r., gdy wydano pierwszą po wojnie ustawę o archiwach. Miała ona tylko kilka punktów, ale stała się podstawą późniejszego prawodawstwa. Zgodnie z duchem marksizmu w ustawie mówiło się, że wszystkie archiwa i ich zasoby składają się na jednolity państwowy zasób archiwalny. Archiwa państwowe pozostawiono pod władzą MSW. Miały być one instytutami naukowo-badawczymi. Stroną teoretyczną prac archiwalnych miały się zajmować komisje metodyczne (vadecké archivne rady). Najwyższym organem archiwalnym została Słowacka Komisja Archiwalna (Slovenská archívna správa), która zaczęła działać od 1 VII 1954 r. Powstały dwa archiwa centralne: Państwowe Centralne Archiwum w Bratysławie i Państwowe Centralne Górnicze Archiwum w Bańskiej Szczawnicy. Archiwa krajowe w Bratysławie, Koszycach, Preszowie, Nitrze, Bańskiej Bystrzycy i Bytczy przemianowano na archiwa państwowe - posiadały one w swoich zasobach archiwalia dawnych żup. Państwowe archiwum w Koszycach jako jedyne na Słowacji miało oddział w Lewoczy, gdzie przechowywano archiwum spiskiej żupy. Przy każdym archiwum państwowym zorganizowano archiwalny oddział MSW, z jego pracownikiem jako naczelnikiem, będącym bezpośrednim organem zarządzającym. W każdym powiecie powstało archiwum powiatowe, które nie podlegało bezpośrednio MSW, ale powiatowym radom narodowym. Ponadto powołano dwa archiwa miejskie, w Bratysławie i w Koszycach.

Obsadę personalną nowo powstałych archiwów stanowili w latach 50. absolwenci teologii, nowicjusze ze zlikwidowanych zakonów lub osoby politycznie niepoprawne. $Z$ jednej strony było to spowodowane faktem, że praca archiwisty nie była społecznie i finansowo atrakcyjna, wymagała znajomości łaciny, niemieckiego i węgierskiego, $\mathrm{z}$ drugiej chodziło o zatrudnienie w archiwach świadomych pracowników i dobrych fachowców. Efektem była systematyczna praca archiwistów, która zaowocowała myślą metodyczną. W 1958 r. wydano podręcznik Základný pravidiel pre prácu s archívnym materialom ${ }^{10}$. Prace inwentaryzacyjno-ewidencyjne w latach 50. i 60. XX w. ukierunkowane były na badania nad historią ruchu komunistycznego w Czechosłowacji i robotniczego ruchu rewolucyjnego.

W połowie lat 6o. XX w. zasób archiwów słowackich liczył 130000 m.b., archiwiści słowaccy współpracowali z kolegami z Węgier i wyjeżdżali na staże do Francji. Powstawały nowe pomieszczenia archiwalne: magazyny, pracownie konserwacji i mikrofilmów, pracownie naukowe i podręczne biblioteki. Sieć archiwów

\footnotetext{
10 Základný pravidiel pre prácu s archívnym materialom, Bratislava 1958.
} 
rozszerzała się o archiwa z powierzonym zasobem. Spod nadzoru państwowej sieci archiwalnej wyjęte były jedynie archiwa milicyjne i partii komunistycznej.

W II połowie lat 6o. XX w. nastała w Czechosłowacji pewna liberalizacja. Po Praskiej Wiośnie doszło do rozdziału władzy nad czeskimi i słowackimi archiwami oraz zlikwidowano nadzór milicyjny nad tymi ostatnimi, choć pozostały one nadal pod zarządem MSW. W 1969 r. dotychczasowe archiwa państwowe zostały przemianowane na wojewódzkie archiwa państwowe, a powiatowe - na powiatowe archiwa państwowe, przez co nie doszło do planowanego ich połączenia. Samodzielność uzyskało archiwum w Lewoczy. Ponadto w 1966 r. zaczęto wydawać główny periodyk słowackich archiwistów „Slovénská archivistika”.

W 1975 r. uchwalono nową, bardziej szczegółową od wcześniejszej, ustawę o archiwach, którą uzupełniały rozporządzenia w wielu przypadkach obowiązujące do dzisiaj. Ustawa regulowała pojęcie dokumentu archiwalnego, kwestie udostępniania i ochrony zasobu archiwalnego oraz ustalała organizację archiwów. Bardzo istotnym jej punktem było wprowadzenie dwóch kategorii archiwaliów, określonych jako zabytki kultury (kulturne pamiatky) i narodowe zabytki kultury (národné kulturne pamiatky), które miały podlegać szczególnej ochronie. Rangę tych ostatnich podkreślono zobowiązaniem archiwów do przechowywania ich w osobnym, specjalnie zabezpieczonym miejscu, nawet kosztem wyłączenia z zespołu archiwalnego. Archiwalia z obydwu kategorii nie mogły być udostępniane w oryginale, tylko w kopiach, których wykonanie spadło na właściwe archiwum. Ponadto każde archiwum musiało przedstawiać roczne sprawozdania dotyczące stanu zachowania obydwu rodzajów zabytków kultury. Omawiany przepis ustawy z $1975 \mathrm{r}$. nie utrzymał się długo. W obliczu problemów lokalowych i finansowych, utrudniających sporządzanie kopii zastępczych, zrezygnowano z klasyfikacji archiwaliów, uznając, że mają one taką samą wartość. Obowiązek wykonania kopii jednak pozostał.

Ustawa z 1975 r. spowodowała rozwój infrastruktury archiwów przypadający na lata 70. i 8o. XX w. Polepszyły się w tym czasie przede wszystkim materialne warunki funkcjonowania archiwów. Przykładowo dla Lewoczy oznaczało to daleko idące prace remontowe, mające na celu adaptację renesansowych kamienic na potrzeby archiwum. Obowiązkowa była w tym przypadku wymiana instalacji elektrycznej, zabezpieczenie przed wilgocią i grzybem, przystosowanie poszczególnych pomieszczeń do roli magazynów archiwalnych. Problemy lokalowe archiwów były na Słowacji palące jeszcze w XIX w. Dotyczy to również wszystkich archiwów spiskich, które wielokrotnie zmieniały lokalizację, co związane było z tendencją do pozbywania się w tym czasie archiwaliów z domów żupnych i ratuszów, a także 
z brakiem wolnych pomieszczeń na ich przechowywanie i dość niefrasobliwym podejściem władz do zagadnienia. Obecnie warunki lokalowe słowackich archiwów są stabilne, choć występują między nimi znaczące różnice w standardzie. Na Spiszu inne warunki ma archiwum w Lewoczy, zlokalizowane na głównym rynku miejskim, w dostosowanej do potrzeb instytucji kamienicy, a inne w Starej Lubowli, mieszczące się w dawnym hotelu robotniczym. Niemniej i w jednym, i w drugim przypadku korzystanie z oryginałów średniowiecznych dokumentów jest tak samo ekscytujące.

Jeśli chodzi o zarząd nad archiwami słowackimi i ich kadrę, to w końcu lat 70. XX w. zauważalny był coraz wyraźniejszy wpływ organów Komunistycznej Partii Słowacji na ich funkcjonowanie. Kierowników archiwów, archiwistów z wykształcenia, zastępowali coraz częściej niekompetentni członkowie KPS.

Przeobrażenia polityczne po 1989 r. nie wpłynęły w istotny sposób na archiwa słowackie. Nastąpił częściowy powrót kierowników archiwów odsuniętych z powodów politycznych, ale w większości kadry archiwalne pozostały bez zmian. W latach 1991-1992 znowelizowano ustawę z 1975 r. Zmiany nie dotyczyły jednak podstawowych przepisów prawa archiwalnego, a bardziej stosowanej nomenklatury. Z ustawy usunięto słowo „socjalistyczny” i dostosowano niektóre pojęcia do ówczesnej sytuacji prawnej. Pozostawiono np. termin „jednolitego zasobu archiwalnego Republiki Słowackiej”, usuwając z niego słowo „państwowy”. Archiwa powiatowe pozostały pod zarządem urzędów powiatowych, a nazwę Państwowe Centralne Archiwum Socjalistycznej Republiki Słowacji zamieniono na Słowackie Archiwum Narodowe. Do przepisów wprowadzono prawo do powszechnego dostępu do archiwaliów i badania ich już po 30 latach od przekazania materiałów do archiwum - we wcześniejszej ustawie obowiązywał okres 50 lat.

Od 1 I 1993 r. Słowacja zaczęła funkcjonować jako suwerenne państwo. Dla archiwów oznaczało to utratę swego rodzaju niezależności i wynikającej stąd rangi jako departamentu w MSW Republiki Słowackiej. Archiwa stały się w strukturze ministerstwa jedynie Wydziałem Archiwistyki i Registratur. W 2002 r. uchwalono na Słowacji nową ustawę o archiwach. Zasadniczą zmianą, jaką wprowadzono, było zastąpienie pojęcia „,jednolity zasób archiwalny Republiki Słowackiej” określeniem „archiwalne dziedzictwo Republiki Słowackiej”, które wedle słów ustawy było częścią dziedzictwa kulturalnego państwa. W praktyce oznacza to, że archiwa muszą sprawować nadzór nad całą dokumentacją wytwarzaną w kraju przez wszelkie instytucje, firmy, małe zakłady produkcyjne, rzemieślników, osoby prawne itd., bez względu na to, czy ma ona charakter materiałów archiwalnych, czy też nie, ponieważ ta dokumentacja traktowana jest jako własność państwa. Z tego wynika, 
że każdy, kto w jakikolwiek sposób nabył dokument archiwalny, ma prawem regulowany obowiązek zgłosić go w archiwum państwowym w celu wpisu do ewidencji. Wszystkie dokumenty archiwalne, nawet te znajdujące się w rękach prywatnych, są niezbywalne. Każdy, również osoba prowadząca prywatną działalność gospodarczą, kto chce zorganizować swoje archiwum, musi uzyskać na to zgodę MSW. Ustawa nakazuje, aby w każdym, nawet najmniejszym archiwum zatrudniona była osoba $\mathrm{z}$ wykształceniem wyższym, posiadająca specjalizację $\mathrm{w}$ archiwistyce i naukach pomocniczych historii. Ponadto na mocy ustawy połączone zostały archiwa państwowe z powiatowymi w ten sposób, że te ostatnie stały się oddziałami zamiejscowymi archiwów państwowych. W końcu 2002 r. działało na podstawie wymienionej ustawy 10 archiwów państwowych i 37 oddziałów zamiejscowych, posiadających zasób liczący 175425 m.b. Z tego opracowanych było $85 \%$ archiwaliów.

Ustawa z 2002 r. zdefiniowała funkcje archiwów na Słowacji. Duże trudności napotkała realizacja przepisów dotyczących zabezpieczenia i udostępnienia archiwaliów. Generalnie archiwa miały umożliwić dostęp do oryginałów dokumentów i akt, państwo zobowiązane było zabezpieczyć archiwalia (szczególnie najcenniejsze), a osoby prawne i instytucje miały w tych działaniach uczestniczyć poprzez udostępnianie własnych zasobów i współdziałanie w tej kwestii z odpowiednimi instytucjami. Jednak w przypadku złego stanu archiwaliów, archiwa powinny udostępniać tylko ich kopie. Jednak ze względu na nakłady finansowe państwa nie wszystkie archiwa stać było na ich wykonanie. Zderzenie przepisów ustawy z rzeczywistością spowodowało, że do rąk użytkowników trafiają najczęściej oryginały dokumentów i akt.

W latach 70. XX w. budowano w archiwach słowackich infrastrukturę związaną z procesem mikrofilmowania archiwaliów. Powstawały służące temu pracownie wyposażone w odpowiedni sprzęt. W latach 90. wykorzystano go m.in. do mikrofilmowania akt stanu cywilnego na potrzeby mormonó $w^{11}$. Nowe wyzwania przyniósł przełom technologiczny związany z digitalizacją archiwaliów. W 2000 r. rozpoczął się proces modernizacji laboratoriów i dostosowania ich do potrzeb cyfryzacji zasobu. Powstał w związku z tym międzyresortowy projekt i jego podprojekt o8Co1 Archívníctvo, zakładający digitalizację dokumentów archiwalnych. Dla archiwów słowackich oznacza to, że od 2009 r. każde z nich musi rocznie wykonać 5000 skanów, co jest trudne do zrealizowania! Archiwista w Polsce może się temu

11 Patrz: https://www.familysearch.org/search/collection/list/?page $=1 \&$ countryId=1927146>, [dostęp 24 listopada 2017 r.]. 
dziwić, ale proces digitalizacji w archiwach słowackich in pleno napotyka szereg trudności. Są one związane, przede wszystkim w tych archiwach, które w zasobie mają liczne dokumenty średniowieczne, ze stanem opracowania dyplomów, a tym samym z zamieszczeniem metadanych odnoszących się do nich i w konsekwencji z możliwością udostępnienia ich w Internecie. Do tego dochodzi zderzenie zamiarów z rzeczywistością, polegające na niskich nakładach finansowych państwa na digitalizację w archiwach. Przykładowo archiwum w Lewoczy do 2016 r. zeskanowało 47 dokumentów herbowych, 1350 dokumentów średniowiecznych, 106 pieczęci, 2242 widokówki, co dało razem 11000 skanów.

Najbardziej palącym problemem słowackich archiwów są archiwa kościelne. Pomimo tego, że ich funkcjonowanie na każdym poziomie regulował Kodeks Prawa Kanonicznego, to duchowieństwo nie poświęcało im stosownej uwagi. Pierwsze próby porządkowania archiwów arcybiskupstw przypadają na XVIII w. W 1786 r. arcybiskup ostrzyhomski Batthyány opracował szczegółowe wskazówki dotyczące układu akt w archiwach. Według nich należało je podzielić na dwie grupy: powstałe do 1775 r. (Archivum vetus) i powstałe po tej dacie (Archivum novum). Tym samym pierwsza grupa tworzyła archiwum właściwe, druga registraturę. W obrębie każdej z nich arcybiskup wprowadził podział rzeczowy akt, który w praktyce był modyfikowany.

Zaproponowane rozwiązania zostały wprowadzone $\mathrm{w}$ życie jedynie $\mathrm{w}$ archiwum biskupstwa ostrzyhomskiego, biskupstwa nitrzańskiego i wikariatu trnawskiego. W innych nie znalazły zastosowania, gdyż kierowano się w nich własnymi doświadczeniami.

Do II wojny światowej archiwa kościelne funkcjonowały bez większych strat. W latach 1948-1956 w związku z nacjonalizacją majątków kościelnych państwo przejęło na własność archiwalia kościelne. Część z nich dostała się do archiwów państwowych, część została zniszczona. Rozpoczęto także ewidencjonowanie archiwów kościelnych. Po uchwaleniu ustawy archiwalnej w 1954 r. rozpoczęto działania zmierzające do zgromadzenia całego zasobu archiwów kościelnych w archiwach państwowych, czego ostatecznie nie zrealizowano.

W 1956 r. na podstawie umów między Kościołem czechosłowackim a państwem doszło do porozumienia, na którego podstawie archiwa kościelne zostały włączone do tzw. operatívnej spravy štátnych archivov. Oznaczało to, że archiwalia pozostały własnością Kościoła, archiwiści państwowi mieli zaś obowiązek zewidencjonować zasób, uwzględnić go we własnej ewidencji i kontrolować stan zabezpieczenia archiwów kościelnych, mogli natomiast na potrzeby archiwów państwowych wypożyczać archiwalia z obowiązkiem zwrotu po okresie wykorzystania. 
W latach 1974-1975 słowaccy archiwiści dokonali kontroli niektórych archiwów kościelnych, stwierdzając, że są one w bardzo złym stanie. Pojawiła się w związku z tym inicjatywa, aby utworzyć przy biskupstwach specjalne archiwa przeznaczone na akta przechowywane w archiwach parafialnych. Do realizacji tego zamysłu nie doszło.

Obecnie archiwa biskupstw na Słowacji nie są dobrze rozpoznane. Nie wiadomo przede wszystkim, czy w ich zasobie znajdują się tylko pozostałości po działalności urzędu biskupa, czy również archiwalia pozostałe po innych instytucjach kościelnych. Stanowiska archiwistów są obsadzone jedynie formalnie i w związku z tym nie prowadzi się $\mathrm{w}$ archiwach żadnych prac. Prowizoryczną pracownię naukową ma jedynie archiwum biskupstwa greckokatolickiego w Preszowie. 